\title{
Coomassie Stainable Particles (CSP): Protein Containing Exopolymer Particles in the Ocean
}

\author{
Daniel C. O. Thornton* \\ Department of Oceanography, Texas A\&M University, College Station, TX, United States
}

\section{OPEN ACCESS}

Edited by:

Gordon T. Taylor,

Stony Brook University, United States

Reviewed by:

Carolina Cisternas Novoa, GEOMAR Helmholtz-Zentrum für Ozeanforschung Kiel, Germany Luisa Galgani,

University of Siena, Italy

${ }^{*}$ Correspondence: Daniel C. O. Thornton dthornton@tamu.edu

Specialty section: This article was submitted to Marine Biogeochemistry, a section of the journal Frontiers in Marine Science

Received: 04 January 2018 Accepted: 28 May 2018

Published: 15 June 2018

Citation: Thornton DCO (2018) Coomassie Stainable Particles (CSP): Protein Containing Exopolymer Particles in the Ocean. Front. Mar. Sci. 5:206. doi: 10.3389/fmars.2018.00206
Exopolymer particles play a significant role in biogeochemical processes in the ocean. Coomassie stainable particles (CSP) are a class of gel-like exopolymer particles that contain protein. CSP are abundant and ubiquitous in the global ocean, from the sea surface microlayer (SML) to depths in excess of $4,000 \mathrm{~m}$. A synthesis of data from the literature estimates a median CSP concentration of $58 \mathrm{~mm}^{2} \mathrm{~L}^{-1}$, with a median particle abundance of $21 \times 10^{6}$ particles $\mathrm{L}^{-1}$. CSP are also abundant in cultures of diatoms, cyanobacteria, and heterotrophic bacteria, indicating that microorganisms are a significant source. Limited data suggest that CSP are more labile and less sticky than transparent exopolymer particles (TEP). CSP are a component of primary organic aerosol and are injected into the atmosphere by bubble bursting. However, it is not known whether CSP contribute to cloud formation by acting as cloud condensation nuclei (CCN) or ice nucleating particles (INP). Better conceptual models of the factors affecting CSP production are needed. These should integrate the physiological ecology of microorganisms producing or degrading CSP with abiotic processes, such as particle aggregation. Whether CSP is a conceptually, rather than operationally, useful definition depends on whether CSP have unique and measurable properties that distinguish them from the bulk dissolved organic matter (DOM) and particulate organic matter (POM) pools, and TEP. A research priority is the development of methods to quantify CSP in terms of biogeochemically significant elements, namely carbon and nitrogen. It is only through quantitative methods that the significance of CSP in processes, such as the biological carbon pump and marine aerosol dynamics, can be determined.

Keywords: Coomassie stainable particles (CSP), dissolved organic matter (DOM), exopolymer, sea surface microlayer (SML), marine aerosol, phytoplankton, transparent exopolymer particles (TEP)

\section{INTRODUCTION}

Since their discovery in the 1990s (Alldredge et al., 1993; Logan et al., 1994; Long and Azam, 1996), interest has grown in the role that gel-like exopolymer particles play in ocean biogeochemistry. Coomassie stainable particles (CSP) are exopolymer particles that were first described from water collected in the coastal Pacific Ocean and Arabian Sea by Long and Azam (1996). CSP are sampled onto $0.4 \mu \mathrm{m}$ pore size polycarbonate filters and the material retained on the filter is stained with a solution of Coomassie Brilliant Blue at pH 7.4 (Long and Azam, 1996). Coomassie Brilliant Blue is a reagent that has been used to quantify proteins for several decades (Bradford, 1976) and therefore CSP are characterized as protein-containing particles (Figure 1A). Unless stained, CSP are invisible when viewed with a microscope using transmitted light. 
To understand CSP in the ocean, it is worthwhile to briefly introduce the other types of exopolymer particles and their detection methods. Transparent exopolymer particles (TEP) are the most studied (see reviews by Passow, 2002a; Bar-Zeev et al., 2015; Mari et al., 2017), reflecting their biogeochemical importance as the "glue" that sticks marine snow aggregates together (Passow, 2002a; Thornton, 2002; Mari et al., 2017) and the relative ease by which TEP can be measured using a spectrophotometric assay (Passow and Alldredge, 1995). TEP are operationally defined as particles retained on $0.4 \mu \mathrm{m}$ (though some researchers use $0.2 \mu \mathrm{m}$; Mari, 2008; Mari and Robert, 2008; Mari et al., 2012) pore size polycarbonate filters that stain with a solution of Alcian blue (Alldredge et al., 1993; Passow and Alldredge, 1995; Passow, 2002a,b) (Figure 1B).
Alcian blue is a cationic dye that stains acid polysaccharides. Much more is known about the characteristics and dynamics of TEP in the ocean, compared with CSP (Mari et al., 2017). Less used methods to detect gel-like exopolymers in seawater include immunostaining using enzyme-linked immonusorbant assays (ELISA) (Orellana et al., 2003, 2011) and staining with chlortetracycline (CTC) (Orellana et al., 2007, 2011). Fluorescent CTC binds to the $\mathrm{Ca}^{2+}$ that stabilize and cross-link the polymer network that form exopolymer particles (Orellana et al., 2007, 2011).

This paper will review what we have learnt about CSP over the last 20 years, focusing on measurements in the field and laboratory, the composition and formation of CSP, whether CSP are a useful concept, and future work.
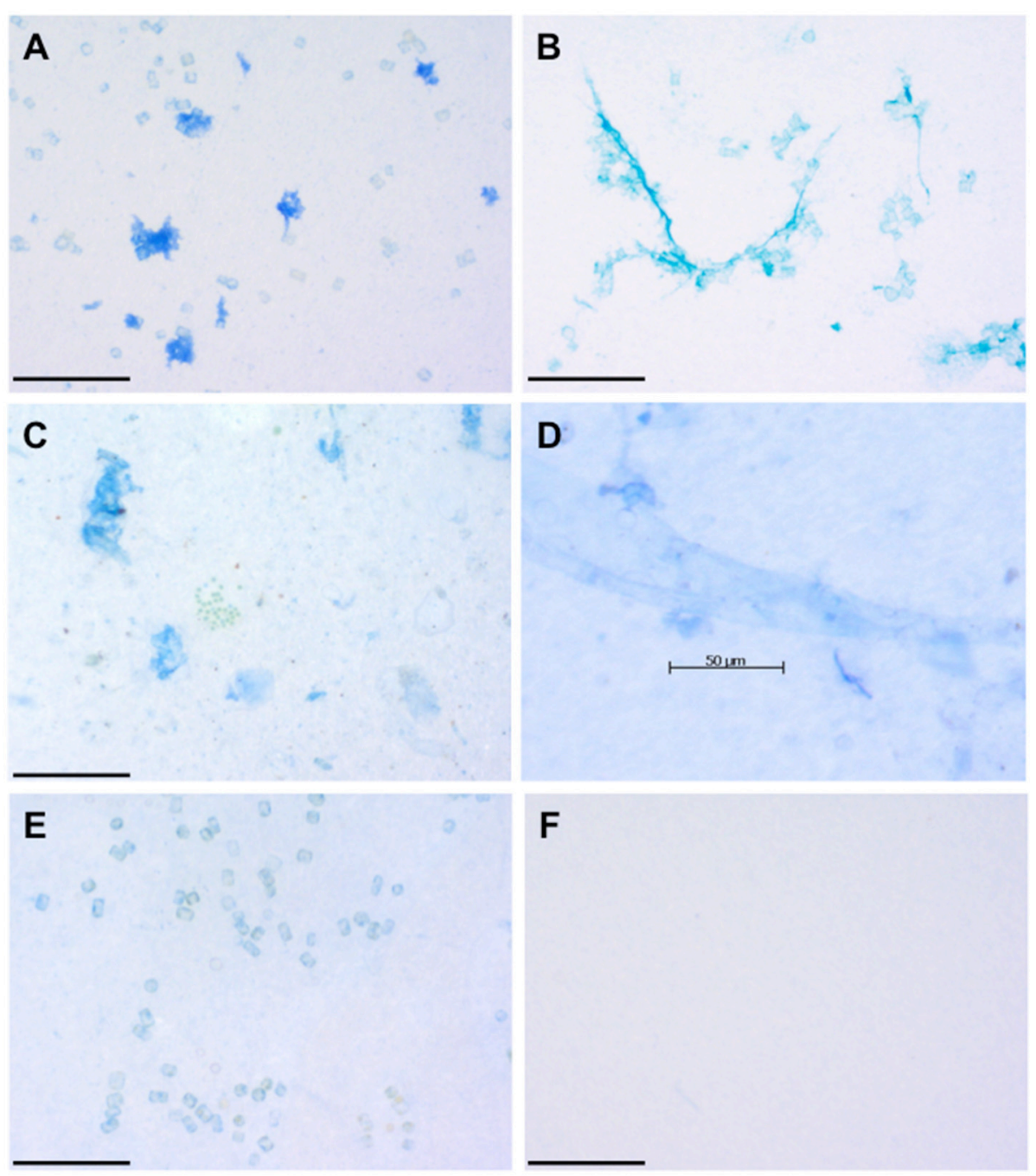

FIGURE 1 | Images of representative exopolymer particles. (A) Coomassie staining particles (CSP) in a culture of the diatom Thalassiosira weissflogii. (B) Transparent exopolymer particles (TEP) sampled at the same time in the culture of Thalassiosira weissflogii. (C) CSP and colonial green phytoplankton collected from the sea surface microlayer (SML) in the Pacific Ocean off the mouth of the Columbia River (July 2011). (D) CSP in the form of a sheet collected from the SML off the coast of Oregon, Pacific Ocean (July 2011). (E) Cell surfaces of the diatom Thalassiosira weissflogii stained with Coomassie brilliant blue. (F) Blank made during field work in the Pacific Ocean by staining the filter with Coomassie brilliant blue. Scale bars are $100 \mu \mathrm{m}(\mathbf{A}, \mathbf{B}, \mathbf{C}, \mathbf{E}, \mathbf{F})$ and $50 \mu \mathrm{m}$ (D) long. All images were captured by Daniel Thornton and have not been previously published. 


\section{COMPILATION OF PUBLISHED CSP DATA}

A compilation of CSP data was obtained from the literature and publically accessible databases (PANGEA; Galgani and Engel, 2013a; Endres et al., 2014; Engel et al., 2015b; Engel and Galgani, 2016a; Galgani et al., 2016b). Numerical data were obtained directly from papers and supplementary material, or indirectly from figures that were analyzed using inverse graphing software (Engauge Digitizer 10.3). Data from the Thornton lab (Thornton et al., 2016; Thornton and Chen, 2017) were obtained from original spreadsheets. Most data were individual data points, though in some cases means and standard deviations were obtained. Data were expressed as exopolymer particle abundance (number of particles $\mathrm{L}^{-1}$ ) and exopolymer particle concentrations in terms of particle area $\left(\mathrm{mm}^{2} \mathrm{~L}^{-1}\right)$. More data were available for particle abundance than concentrations. The CSP data were supported with additional information such as location and sampling depth.

Figure 2A presents a compilation of CSP data from a range of habitats in the field and from laboratory experiments. For comparison, Figure 2B presents TEP data (when available) from the same studies. While Figure $\mathbf{2 A}$ is a comprehensive compilation of the available CSP data, Figure 2B represents a relatively small subset of the published TEP data as most TEP measurements do not have concurrent measurements of CSP. Considering all the data, there was a significant correlation $(r=0.94, p<0.0001, n=439)$ between CSP particle abundance and concentration. CSP and TEP concentrations were correlated $(r=0.44, p<0.0001, n=541)$, as were CSP and TEP particle abundances $(r=0.54, p<0.0001, n=615)$.

The data in Figure 2 were obtained by analysis of images of stained exopolymer particles (see Engel, 2009 for a review of the methods). This analysis results in estimates of exopolymer abundance and exopolymer area per unit volume, with the latter being a more useful estimate of the amount of material in the sample. Potentially, this type of analysis can produce data on particle size, including particle size distributions, with the caveat that the image analysis is based on a two dimensional analysis of a particle that is flattened on the filter, rather than in its three dimensional state in situ. The robust correlations between CSP abundance and concentration indicates that the variation in individual CSP particle size was relatively small over the range of CSP concentrations sampled. Mean CSP size was $109 \pm 187$ $\mu \mathrm{m}^{2}( \pm \mathrm{SD} ; n=369)$ compared with $105 \pm 166 \mu \mathrm{m}^{2}( \pm \mathrm{SD}$; $n=349)$ for TEP. The similarity in mean exopolymer particle size suggests that CSP and TEP may be the same population of particles, which are capable of staining with both Coomassie brilliant blue and Alcian Blue. However, the relatively weak correlations between both CSP and TEP abundances, and CSP and TEP concentrations, suggests that CSP and TEP are not the same populations of particle. This indirect analysis does not preclude some overlap in the two populations (i.e., some particles are composed of both protein and acid polysaccharides).

\section{MEASUREMENTS OF CSP IN THE FIELD}

Most field measurements of CSP have been made in the ocean (Figure 2A), with a limited number of freshwater studies

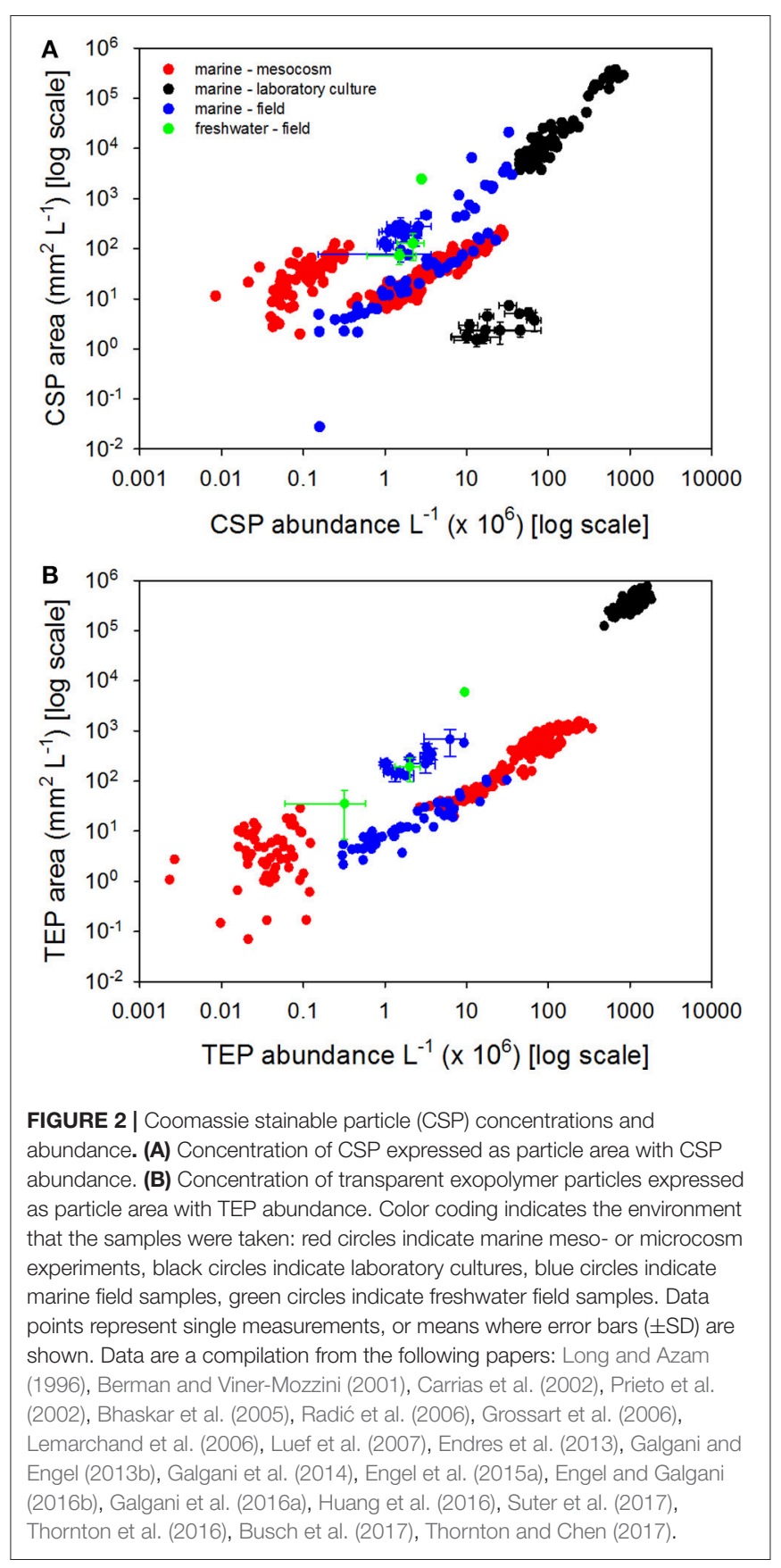

(see Berman and Viner-Mozzini, 2001; Carrias et al., 2002; Lemarchand et al., 2006; Huang et al., 2016). Marine samples have been collected in the Atlantic Ocean, Arabian Sea, Pacific Ocean, and Arctic Ocean. Mean CSP concentrations were $721 \pm 2622$ $( \pm \mathrm{SD})$ with a median of $58 \mathrm{~mm}^{2} \mathrm{~L}^{-1}$ (Figure $2 \mathrm{~A}$ ), compared with TEP concentrations of $87 \pm 142( \pm \mathrm{SD})$ with a median of $20 \mathrm{~mm}^{2} \mathrm{~L}^{-1}$ (Figure 2B). In terms of particle abundance, mean CSP was $47 \times 10^{6} \pm 61 \times 10^{6}( \pm \mathrm{SD})$ with a median of 21 $\times 10^{6}$ particles $\mathrm{L}^{-1}$ (Figure 2A), compared with $15 \times 10^{6} \pm$ $17 \times 10^{6}$ (mean \pm SD) with a median of $9 \times 10^{6}$ particles $\mathrm{L}^{-1}$ for TEP (Figure 2B). The high standard deviations reflect 
that exopolymer particle concentrations and abundance vary substantially in situ, over four orders of magnitude.

In the ocean, field measurements have largely focused on the epipelagic (i.e., $<200 \mathrm{~m}$ depth), and most of those have been concentrated in the upper epipelagic, including the sea surface micro layer (SML) (Engel and Galgani, 2016b; Galgani et al., 2016a; Thornton et al., 2016). There is a paucity of measurements at depths below the epipelagic zone. This could reflect an assumption that CSP are produced by phytoplankton and are rapidly remineralized below the euphotic due to their high protein content, or simply be a question of resources. In addition to the original measurements of CSP in the Arabian Sea (Long and Azam, 1996), depth profiles into the bathypelagic have been made in the Arctic Ocean (Fram Strait) and Atlantic Ocean (Sargasso Sea) (Cisternas-Novoa et al., 2015; Busch et al., 2017). Data from Cisternas-Novoa et al. (2015) were not included in the database as they were obtained with methods that are not directly comparable to CSP data obtained using imaging methods. They measured both TEP (Passow and Alldredge, 1995) and CSP (Cisternas-Novoa et al., 2014) using semi-quantitative spectrophotometric methods in which the concentration of exopolymer particles was expressed as a concentration in terms of equivalents of a standard. Like Long and Azam (1996) and Busch et al. (2017), they showed that CSP are present throughout the water column, to depths greater than $4,000 \mathrm{~m}$ (Cisternas-Novoa et al., 2015).

While limited, these data suggest that CSP is ubiquitous and found in similar concentrations (both in terms of area and particle concentration) as TEP. Mari et al. (2017) estimate that TEP production rate in the ocean is 2.5 to $5 \mathrm{Pg} \mathrm{C} \mathrm{yr}^{-1}$. If rates of CSP production are similar, then a significant proportion $(5$ to $10 \%$ ) of annual primary productivity (45 to $55 \mathrm{Pg} \mathrm{C} \mathrm{yr}^{-1}$; Longhurst et al., 1995; Field et al., 1998; Falkowski et al., 2000; Carr et al., 2006; Westberry et al., 2008) passes through the CSP pool.

\section{MANIPULATIVE EXPERIMENTS IN THE LABORATORY AND FIELD}

Manipulative experiments have been used as a tool to determine what factors affect CSP production. These experiments fall into two categories; manipulative experiments using natural biological communities grown under approximations of in situ conditions in micro- or mesocosms (Prieto et al., 2002; Radić et al., 2006; Galgani et al., 2014; Engel et al., 2015a), and laboratory experiments with defined cultures of microorganisms (Bhaskar et al., 2005; Grossart et al., 2006; Endres et al., 2013; Galgani and Engel, 2013b; Thornton, 2014; Thornton and Chen, 2017). Experiments in micro- and mesocosms have been simulations of different ocean acidification conditions (Galgani et al., 2014) or manipulations of nutrient ratios and availability (Radić et al., 2006; Engel et al., 2015a). Engel et al. (2015a) found that TEP were more abundant than CSP, and both exopolymer particles were positively correlated with chlorophyll a concentration, suggesting that phytoplankton were the primary source of the expolymers. As the bloom collapsed, particle size distributions suggested that TEP aggregated into larger particles whereas CSP degraded.

Laboratory experiments on CSP production have been conducted with cultures of diatoms (Bhaskar et al., 2005; Grossart et al., 2006; Galgani and Engel, 2013b; Thornton, 2014; Thornton and Chen, 2017) and cyanobacteria (Endres et al., 2013; Cisternas-Novoa et al., 2015; Thornton and Chen, 2017); other major phylogenetic groups of phytoplankton have been overlooked. Phytoplankton, heterotrophic protists and heterotrophic prokaryotes are potentially significant sources of the exopolymers that form CSP. Heteterotrophic prokaryotes, heterotrophic protists, and mixotrophic phytoplankton may affect the breakdown of CSP. The relationships and interactions between organisms that affect CSP concentrations are unknown and likely complex.

CSP are widely produced by diatoms as they have been found in cultures of a range of taxa grown under a range of conditions (Galgani and Engel, 2013b; Thornton, 2014; Thornton and Chen, 2017). Endres et al. (2013) grew the cyanobacterium Nodularia spumigena under a range of atmospheric $p \mathrm{CO}_{2}$ and found that more CSP was produced at higher $p \mathrm{CO}_{2}$. Endres et al. (2013) hypothesized that degradation of the CSP resulted in an increase in particles of smaller size at lower $p \mathrm{CO}_{2}$ concentrations. CSP are present in cultures of Synechococcus (Cisternas-Novoa et al., 2015; Thornton and Chen, 2017), a widely distributed cyanobacterium of global significance. Research indicates that CSP is more labile than TEP (Endres et al., 2013; Engel et al., 2015a), which is not surprising given the relatively high nitrogen content of CSP. In addition to degrading CSP, heterotrophic bacteria are also a potential source. Radić et al. (2006) conducted nutrient addition microcosm experiments with filtered $(1 \mu \mathrm{m})$ Adriatic seawater in which phytoplankton were largely excluded. Large ( $>4 \mu \mathrm{m}$ in length) CSP and TEP particles were produced in concentrations of $10^{4}$ to $10^{5} \mathrm{~L}^{-1}$. Bhaskar et al. (2005) found that CSP and TEP formed in roller tank experiments containing exopolymers isolated from cultures of Marinobacter sp. Marinobacter adhaerens enhanced the production of TEP by Thalassiosira weissflogii, but only when the diatom was not nutrient limited (Gärdes et al., 2012); similar interactions between organisms and the environment are likely to affect CSP production. Grossart et al. (2006) found that CSP and TEP produced by Thalassiosira rotula were relatively recalcitrant compared with those released by Skeletonema costatum, which were rapidly degraded by free-living bacteria.

\section{CSP FORMATION AND COMPOSITION}

While staining with Coomassie brilliant blue tells us that CSP contain proteins, it does not give any information on the composition of those proteins and whether or not the protein is associated with other biopolymers. A key question is the degree of overlap between CSP and TEP. Ideally, researchers would be able to stain for TEP and CSP on the same filters to determine whether they are separate populations of exopolymer particles, or if the Alcian blue and Coomassie brilliant blue staining polymers are components of the same particles. Unfortunately, this is 
not possible as both classes of exopolymer particle are stained with similar looking blue dyes, which makes visualization on the same slide extremely challenging (compare Figures 1A,B). Despite this limitation, recent work indicates that TEP and CSP are different populations of exopolymer particles. CisternasNovoa et al. (2015) used a novel FlowCam imaging technique and determined that CSP and TEP were different particles in cultures of the diatom T. weissflogii and cyanobacterium Synechococcus bacillaris. Thornton and Chen (2017) measured TEP and CSP concentrations in cultures of T. weissflogii and Synechococcus elongatus. TEP and CSP concentrations were not significantly correlated in terms of both concentration (area per unit volume) and numbers of particle. In situ measurements also indicate that TEP and CSP behave differently and represent different populations of exopolymer particle. Thornton et al. (2016) measured CSP and TEP in the sea surface microlayer (SML) and underlying water in the coastal Pacific Ocean and found that CSP, but not TEP, was concentrated in the SML relative to the underlying water. Cisternas-Novoa et al. (2015) measured depth profiles of CSP and TEP in the Sargasso Sea and concluded that they are different populations of exopolymer particles produced by different organisms.

The composition of the proteins that make CSP has not been characterized, but if it is assumed that CSP are largely derived from phytoplankton then it is likely that the composition of CSP reflects the composition of proteins produced by phytoplankton. Protein is a major component of phytoplankton cells (65\% by weight; Hedges et al., 2002). Phytoplankton are known to release dissolved organic nitrogen (DON), including proteins, into the surrounding medium (Bronk et al., 1994; Glibert and Bronk, 1994; Hu and Smith, 1998; Suratman et al., 2008). Myklestad (2000) reviewed the literature and conclude that diatoms commonly release the following amino acids: serine, glycine, alanine, glutamic acid, aspartic acid, ornithine, and histidine. Accumulation of protein-containing fluorescent dissolved organic matter (FDOM) during phytoplankton growth (Stedmon and Markager, 2005; Romera-Castillo et al., 2010) indicates that phytoplankton release also includes fluorescent amino acids, such as tryptophan, tyrosine, and phenylalanine (Coble, 1996). The stoichiometric formula for plankton protein derived by Hedges et al. (2002) has a C:N ratio of 3.8:1, which is significantly lower than the Redfield ratio of 6.6:1 (Redfield, 1958). In contrast, estimates of the mean C:N ratio for TEP are 20:1 (Mari et al., 2001) and 26:1 (Engel and Passow, 2001). Assuming that CSP has a C:N ratio similar to that of average plankton protein, then the nitrogen content of CSP is five to seven times greater than in TEP. Changes in the ratio of TEP to CSP could influence the C: $\mathrm{N}$ ratio of organic matter in the water column, which may affect rates of remineralization of sinking organic matter and the abundance and composition of associated microbial communities. CSP could also serve as a nitrogen-rich carbon source for grazing protists and animals.

Chin et al. (1998) showed that DOM polymers abiotically and spontaneously assemble into exopolymer gels. TEP formation from biological precursors is believed to be an abiotic process, as shown from experiments where TEP accumulates in $0.2 \mu \mathrm{m}$ filtrate from diatom cultures that is exposed to laminar shear in a
Couette flocculator (Passow, 2000) or bubbled with air (Mopper et al., 1995; Mari, 1999). CSP often forms thin sheets (Long and Azam, 1996; Thornton et al., 2016), which suggests that interfaces and surfaces may play an important role in their formation. A hypothesis to explain CSP formation is that surface-active precursors are concentrated at the sea surface by rising bubbles (Wurl and Holmes, 2008; Thornton et al., 2016). Assembly of CSP precursors at the air-sea interface would result in thin sheets of CSP forming. The hydrophobic properties of amino acids with aliphatic and aromatic side chains (Cunliffe et al., 2013) may play a role in the aggregation of proteins into exopolymer particles in the sea surface microlayer (SML) (Figures 1C,D). Alternatively, the SML is often enriched in microorganisms (Aller et al., 2005), with a community composition different from the underlying water (Cunliffe and Murrell, 2009; Taylor and Cunliffe, 2014); elevated CSP concentrations in the SML may reflect differences in microbial community composition compared with the underlying waters and the fact that the SML is a relatively stressful environment (Cunliffe et al., 2011).

TEP often have a density significantly lower than seawater (Azetsu-Scott and Passow, 2004), and therefore ascend through the water column, which has been proposed as a mechanism to account for their enrichment in the SML (Wurl et al., 2011). This mechanism is not counter to their role in downward flux of organic matter via the biological pump as sticky TEP glue together ballasted aggregates of particles (e.g., phytoplankton) that are significantly denser than seawater (Passow, 2002a; Thornton, 2002; Mari et al., 2017). The density of CSP has not been measured, and therefore it is not known whether the accumulation of CSP in the SML (Thornton et al., 2016) is due to CSP ascending through the water column due to local production, positive bouyancy, bubble scavenging, or a combination of these processes.

The physiology and underlying genomics of CSP production by phytoplankton and other marine microorganisms are unknown. Thornton and Chen (2017) tested the hypothesis that stress and cell death affected expolymer particle production in a diatom (T. weissflogii) and the cyanobacterium (S. elongatus). It was found that TEP production was enhanced by the stressor $\mathrm{H}_{2} \mathrm{O}_{2}$ (a reactive oxidative species), which did not affect the production of CSP. TEP concentration was correlated with indicators of stress and cell death, namely a decrease in the quantum yield of photosystem II, an increase in caspase-like enzyme activity, and an increase in the proportion of the population with permeable cell membranes as indicated by SYTOX Green staining. CSP concentrations did not correlate with these indicators of stress and there was no significant correlation between CSP and TEP concentrations. These results support field observations that imply that TEP and CSP are different populations of exopolymer particles formed through different processes.

While physiological processes are a major route for the release of CSP precursors by phyto- and bacterioplankton, it should be noted that the physical disruption of the cells, through mechanisms such as sloppy feeding by grazers (Møller et al., 2003; Møller, 2007) and viral lysis (Bratbak et al., 1993; Gobler et al., 1997; Mojica et al., 2016), may also play a 
significant role in CSP production. In situ, the production of CSP precursors will be effected by environmental constraints such as nutrient and light availability, and a complex web of interactions between organisms in the ecosystem, affecting the production and degradation of exopolymers.

\section{CSP IN THE SEA SURFACE MICRO LAYER (SML) AND ATMOSPHERE}

There is a growing interest in the connection between marine ecosystem function and the properties of marine aerosol (O’Dowd et al., 2004; Quinn and Bates, 2011; Wilson et al., 2015; Brooks and Thornton, 2018). Aerosols are significant drivers of climate as they scatter light, seed warm clouds by acting as cloud condensation nuclei (CCN), and ice clouds by acting as ice nucleating particles (INP) (Brooks and Thornton, 2018). Aerosols, and the clouds that grow on them, profoundly affect the Earth's radiative budget and the strength and even direction of forcing remain a major uncertainty in climate models (IPCC, 2014).

Transmission electron microscopy (TEM) of marine aerosol has revealed gel-like exopolymeric material in aerosol collected over the Arctic Ocean (Leck and Bigg, 2005, 2008) and in the tropics off the Great Barrier Reef (Leck and Bigg, 2008). Leck and Bigg (2008) exposed this material to flavianic acid solutions and found that the particles broke apart, suggesting that they contained amino acids and proteins. Orellana et al. (2011) proposed that exopolymer particles were important CCN over the Arctic Ocean based on the observation of numerous nanogel particles in cloud samples, the SML and underlying water. Orellana et al. (2011) did not measure TEP or CSP; gel particles were visualized using chlorotetracycline and an enzymelinked immunosorbent assay (ELISA).

The ocean forms an interface with the atmosphere over $71 \%$ of the Earth's surface and mechanisms, such as bubble-bursting from air entrained when waves break, throw sea spray aerosol droplets into the atmosphere (Russell et al., 2010; Cochran et al., 2017). The SML plays an important role in these processes; it is a distinct layer at the surface of the ocean with measurably different properties from the underlying water (Hunter, 1997; Zhang et al., 2003). Several studies have shown that TEP is frequently concentrated in the SML compared with underlying waters (Wurl and Holmes, 2008; Wurl et al., 2011; Cunliffe et al., 2013). Two field studies have investigated upwelling areas in the Eastern Pacific, showing that CSP and TEP were present in SML samples collected off Peru (Engel and Galgani, 2016b) and Oregon (Thornton et al., 2016; Figures 1C,D). Galgani et al. (2014) found abundant CSP in the SML during a mescocosm experiment using water from Raunefjord in Norway during late spring.

Whether CSP is transferred from ocean to atmosphere and whether it has a significant effect on atmospheric processes is largely unknown. Kuznetsova et al. (2005) conducted experiments in both the laboratory and field in which natural seawater was bubbled and the resulting aerosol were collected for chemical analysis, and compared with the SML and underlying water. The aerosols were enriched in amino acids and contained CSP. The enrichment factor, compared with bulk water, for CSP was $5.3 \mathrm{x}$ for the SML and $53 \mathrm{x}$ for sea spray aerosol (Kuznetsova et al., 2005). The results suggested that scavenging on bubbles and bursting through the SML were important in the transfer of CSP to aerosol. Aller et al. (2017) found a CSP enrichment factor in the SML of $11 \mathrm{x}$ compared with the underlying water in the Atlantic Ocean and CSP were also abundant in sea spray aerosol.

\section{SUGGESTIONS FOR FUTURE WORK}

The utility of the CSP concept depends on whether CSP are a large pool of organic matter, and whether they have unique and measurable properties that distinguish them from the bulk DOM and POM pools. Further measurements of CSP distribution in both space and time will help determine whether CSP are the major pool of organic matter that current data suggests. Quantification of CSP in terms of carbon or nitrogen would facilitate the comparison of CSP to other pools of organic matter in the ocean and will enable researchers to incorporate CSP into biogeochemical models and budgets.

Currently, the commonly measured classes of exopolymer particles are operationally defined based on retention on a particular pore-sized polycarbonate filter and staining with specific dyes. The degree of staining cannot be converted into a biogeochemically significant measurement. This is the case for both image analysis of stained CSP (Engel, 2009) and the semi-quantitative spectrophotometric assay in which the concentration of CSP is expressed in terms of equivalents of a standard (bovine serum albumin) that stains with Coomassie brilliant blue (Cisternas-Novoa et al., 2014). The staining behavior of bovine serum albumin is unlikely to reflect the staining behavior of natural CSP under all conditions. Characterizing the protein composition of CSP may provide insights into its properties or source. It is also important to determine whether CSP are pure protein or mixture of different biopolymers. One approach would be to stain exopolymer particles with multiple dyes on the same filter. For example, dyes such as Coomassie Brilliant Blue and Alcian blue (Figures 1A,B) could be combined with fluorescent dyes or lectins to probe whether exopolymer particles are homogenous or heterogeneous in terms of chemical composition and physical structure. This approach is challenging due to the potential interference between different stains and the different conditions under which they are effective.

While filtration enables the collection of exopolymer particles, the material on the filter will include microorganisms and detritus, therefore any chemical characterization will be misleading if it is considered to consist only of expolymer particles. As exopolymer particles are a range of sizes and shapes, there is not a single filter or sequence of filters that can be used to separate CSP from other particulate material. The inability to separate expolymer particles from other matter in the water column is a major barrier to their characterization. Moreover, not all the material that stains with dyes represent the gel-like exopolymer particles that are considered to be CSP and TEP. As 
Figure 1E shows, the surfaces of diatoms are sometimes coated in sufficient protein to adsorb the dye. While these proteins may slough off the diatom cells and contribute to CSP, the diatoms themselves should not be considered to be CSP (Figures 1E,F). Mari and Dam (2004) took advantage of the sticky properties of TEP to isolate them using $1 \mu \mathrm{m}$ diameter magnetic microspheres, but similar methods have not been applied to CSP. This approach has drawbacks as if the microspheres can become imbedded in the exopolymer particles, then presumably other particles are as well, and it assumes that CSP are significantly sticky.

Stickiness is an important property of exopolymer particles as sticky particles are more likely to aggregate organic matter into larger particles that sink faster through the water column, affecting the biological carbon pump. If CSP play a significant role in the export of carbon from surface waters, then they should be a significant component of marine snow aggregates. Staining marine snow with Coomassie brilliant blue could be used to determine whether CSP contributes to the matrix holding marine snow aggregates together as has been shown for TEP (Passow and Alldredge, 1995; Passow, 2002a). Secondly, work in the late 1990s related stickiness [ $\alpha$, the probability of two particles sticking together on collision (Jackson, 1990; Engel, 2000)] to the concentration of TEP (Dam and Drapeau, 1995; Kiørboe et al., 1998; Engel, 2000). However, this work did not account for the presence of CSP. Similar approaches could be used to both determine whether CSP plays a significant role in aggregation and to distinguish it from TEP effects.

Phytoplankton and other microorganisms are assumed to be the primary source of the proteins that make CSP. However, there has been little work on the physiology of CSP production. Work is needed to determine which organisms are significant sources of CSP and whether they are producing CSP directly or releasing dissolved precursors into the water that aggregate into exopolymer particles through abiotic processes. Dissolved organic matter (DOM) release by phytoplankton accounts for 2 to $50 \%$ of the carbon fixed by photosynthesis (Thornton, 2014). Higher rates of release frequently associated with stressors such as high light intensity and nutrient limitation; it is not known how these factors affect CSP production.

The molecular level composition of DOM produced by phytoplankton and bacteria is poorly characterized (Kujawinski, 2011) and the development of ultra-high resolution mass spectroscopy techniques coupled with computational tools for assigning chemical formulae (Longnecker and Kujawinski, 2017; Tolić et al., 2017) is providing new insights (Paul et al., 2009; Longnecker et al., 2015). Characterization of the exometabolome

\section{REFERENCES}

Alldredge, A. L., Passow, U., and Logan, B. E. (1993). The abundance and significance of a class of large, transparent organic particles in the ocean. Deep Sea Res. I 40, 1131-1140. doi: 10.1016/0967-0637(93)90129-Q

Aller, J. Y., Kuznetsova, M. R., Jahns, C. J., and Kemp, P. F. (2005). The sea surface microlayer as a source of viral and bacterial enrichment in marine aerosols. J. Aerosol Sci. 36, 801-812. doi: 10.1016/j.jaerosci.2004.10.012

Aller, J. Y., Radway, J. C., Kilthau, W. P., Bothe, D. W., Wilson, T. W., Vaillancourt, R. D., et al. (2017). Size-resolved characterization of the polysaccharidic and and exoproteome (i.e., DOM released into the surrounding water) may facilitate the characterization of CSP and its precursors. Given that CSP is defined by its protein content, exoproteomics would be the most useful approach. While correlations with CSP concentration and the concentration or specific proteins in DOM may indicate that they are significant components of CSP, confirmation would require the analysis of isolated CSP.

Figure 2A shows that very high concentrations of CSP are possible in phytoplankton cultures. If we assume that the TEP or CSP are $1 \mu \mathrm{m}$ thick sheets, then a volume of 1 $\mathrm{cm}^{3}$ of exopolymer particle would have an area of 100,000 $\mathrm{mm}^{2}$ if it was retained on a filter and analyzed using image analysis (i.e., considering the upward facing area visible on the filter). This area would be equivalent to a volume concentration of 1 part per thousand if it were in a liter of culture. Consequently, in dense phytoplankton cultures it is possible to have concentrations of exopolymer particles greater than $10^{5} \mathrm{~mm}^{2} \mathrm{~L}^{-1}$. However, given that the median CSP concentration in the ocean is $58 \mathrm{~mm}^{2} \mathrm{~L}^{-1}$, such high CSP concentrations in laboratory cultures are unrealistic and may result in CSP dynamics that do not occur naturally. Experiments with laboratory cultures should be conducted at lower biomasses that would likely lead to lower and more realistic CSP concentrations.

In conclusion, the priorities for CSP research should be: (1) the development of methods that quantify CSP in terms of biogeochemically important elements (i.e., carbon and nitrogen), (2) more data on the distribution of CSP (particularly at undersampled depths below the euphotic zone), (3) determination of the stickiness of CSP to assess whether they play a significant role in the biological carbon pump.

\section{AUTHOR CONTRIBUTIONS}

DT conceived this work, compiled and analyzed published data, and wrote the manuscript.

\section{FUNDING}

DT was supported by the National Science Foundation (United States) under Grant No. AGS 1539881 to Sarah D. Brooks and DT. Any opinions, findings, and conclusions or recommendations expressed in this material are those of the author and do not necessarily reflect the views of the National Science Foundation. proteinaceous components of sea spray aerosol. Atmos. Environ. 154, 331-347. doi: 10.1016/j.atmosenv.2017.01.053

Azetsu-Scott, K., and Passow, U. (2004). Ascending marine particles: significance of transparent exopolymer particles (TEP) in the upper ocean. Limnol. Oceanogr. 49, 741-748. doi: 10.4319/lo.2004.49. 3.0741

Bar-Zeev, E., Passow, U., Castrillon, S. R. V., and Elimelech, M. (2015). Transparent exopolymer particles: from aquatic environments and engineered systems to membrane biofouling. Environ. Sci. Technol. 49, 691-707. doi: $10.1021 /$ es5041738 
Berman, T., and Viner-Mozzini, Y. (2001). Abundance and characteristics of polysaccharide and proteinaceous particles in Lake Kinneret. Aquat. Microb. Ecol. 24, 255-264. doi: 10.3354/ame024255

Bhaskar, P. V., Grossart, H. P., Bhosle, N. B., and Simon, M. (2005). Production of macroaggregates from dissolved exopolymeric substances (EPS) of bacterial and diatom origin. FEMS Microbiol. Ecol. 53, 255-264. doi: 10.1016/j.femsec.2004.12.013

Bradford, M. M. (1976). Rapid and sensitive method for quantitation of microgram quantities of protein utilizing principle of protein-dye binding. Anal. Biochem. 72, 248-254. doi: 10.1016/0003-2697(76)90527-3

Bratbak, G., Egge, J. K., and Heldal, M. (1993). Viral mortality of the marine alga Emiliania huxleyi (haptophyceae) and termination of algal blooms. Mar. Ecol. Prog. Ser. 93, 39-48. doi: 10.3354/meps093039

Bronk, D. A., Glibert, P. M., and Ward, B. B. (1994). Nitrogen uptake, dissolved organic nitrogen release, and new production. Science 265, 1843-1846. doi: $10.1126 /$ science. 265.5180 .1843

Brooks, S. D., and Thornton, D. C. O. (2018). Marine aerosols and clouds. Annu. Rev. Mar. Sci. 10, 289-313. doi: 10.1146/annurev-marine-121916063148

Busch, K., Endres, S., Iversen, M. H., Michels, J., Nöthig, E. M., and Engel, A. (2017). Bacterial colonization and vertical distribution of marine gel particles (TEP and CSP) in the Arctic Fram Strait. Front. Mar. Sci. 4:166. doi: $10.3389 /$ fmars.2017.00166

Carr, M. E., Friedrichs, M. A. M., Schmeltz, M., Aita, M. N., Antoine, D., Arrigo, K. R., et al. (2006). A comparison of global estimates of marine primary production from ocean color. Deep Sea Res. II 53, 741-770. doi: 10.1016/j.dsr2.2006.01.028

Carrias, J. F., Serre, J. P., Sime-Ngando, T., and Amblard, C. (2002). Distribution, size, and bacterial colonization of pico- and nano-detrital organic particles (DOP) in two lakes of different trophic status. Limnol. Oceanogr. 47, 1202-1209. doi: $10.4319 /$ lo.2002.47.4.1202

Chin, W. C., Orellana, M. V., and Verdugo, P. (1998). Spontaneous assembly of marine dissolved organic matter into polymer gels. Nature 391, 568-572. doi: $10.1038 / 35345$

Cisternas-Novoa, C., Lee, C., and Engel, A. (2014). A semi-quantitative spectrophotometric, dye-binding assay for determination of coomassie blue stainable particles. Limnol. Oceanogr. Methods 12, 604-616. doi: 10.4319/lom.2014.12.604

Cisternas-Novoa, C., Lee, C., and Engel, A. (2015). Transparent exopolymer particles (TEP) and coomassie stainable particles (CSP): differences between their origin and vertical distributions in the ocean. Mar. Chem. 175, 56-71. doi: 10.1016/j.marchem.2015.03.009

Coble, P. G. (1996). Characterization of marine and terrestrial DOM in seawater using excitation emission matrix spectroscopy. Mar. Chem. 51, 325-346. doi: 10.1016/0304-4203(95)00062-3

Cochran, R. E., Ryder, O. S., Grassian, V. H., and Prather, K. A. (2017). Sea spray aerosol: the chemical link between the oceans, atmosphere, and climate. Acc. Chem. Res. 50, 599-604. doi: 10.1021/acs.accounts.6b00603

Cunliffe, M., Engel, A., Frka, S., Gasparovic, B., Guitart, C., Murrell, J. C., et al. (2013). Sea surface microlayers: a unified physicochemical and biological perspective of the air-ocean interface. Prog. Oceanogr. 109, 104-116. doi: 10.1016/j.pocean.2012.08.004

Cunliffe, M., and Murrell, J. C. (2009). The sea-surface microlayer is a gelatinous biofilm. ISME J. 3, 1001-1003. doi: 10.1038/ismej.2009.69

Cunliffe, M., Upstill-Goddard, R. C., and Murrell, J. C. (2011). Microbiology of aquatic surface microlayers. FEMS Microbiol. Rev. 35, 233-246. doi: $10.1111 / j .1574-6976.2010 .00246 . x$

Dam, H. G., and Drapeau, D. T. (1995). Coagulation efficiency, organicmatter glues and the dynamics of particles during a phytoplankton bloom in a mesocosm study. Deep Sea Res. II 42, 111-123. doi: 10.1016/0967-0645(95)00007-d

Endres, S., Unger, J., Wannicke, N., Nausch, M., Voss, M., and Engel, A. (2013). Response of Nodularia spumigena to $p \mathrm{CO}_{2}$ - Part 2: exudation and extracellular enzyme activities. Biogeosciences 10, 567-582. doi: 10.5194/bg-10567-2013

Endres, S., Unger, J., Wannicke, N., Nausch, M., Voss, M., and Engel, A. (2014). Experiment: response of Nodularia spumigena to $p \mathrm{CO}_{2}$. PANGAEA. doi: 10.1594/PANGAEA.829084
Engel, A. (2000). The role of transparent exopolymer particles (TEP) in the increase in apparent particle stickiness $(\alpha)$ during the decline of a diatom bloom. J. Plankton Res. 22, 485-497. doi: 10.1093/plankt/22.3.485

Engel, A. (2009). "Determination of marine gel particles," in Practical Guidelines for the Analysis of Seawater, ed O. Wurl (Boca Raton, FL: CRC Press), 125-142.

Engel, A., Borchard, C., Loginova, A., Meyer, J., Hauss, H., and Kiko, R. (2015a). Effects of varied nitrate and phosphate supply on polysaccharidic and proteinaceous gel particle production during tropical phytoplankton bloom experiments. Biogeosciences 12, 5647-5665. doi: 10.5194/bg-12-5647-2015

Engel, A., and Galgani, L. (2016a). The organic sea-surface microlayer in the upwelling region off the coast of Peru and potential implications for air-sea exchange processes Fig 1-6, 9. PANGAEA. doi: 10.1594/PANGAEA.859850

Engel, A., and Galgani, L. (2016b). The organic sea-surface microlayer in the upwelling region off the coast of peru and potential implications for air-sea exchange processes. Biogeosciences 13, 989-1007. doi: 10.5194/bg-13-989-2016

Engel, A., Borchard, C., Loginova, A., Meyer, J., Hauss, H., and Kiko, R. (2015b). Mesocosm experiment Cape Verde 2012: chromophoric and fluorescent dissolved organic matter, polysaccharidic and proteinaceous gel particles production. PANGAEA. doi: 10.1594/PANGAEA. 847693

Engel, A., and Passow, U. (2001). Carbon and nitrogen content of transparent exopolymer particles (TEP) in relation to their Alcian Blue adsorption. Mar. Ecol. Prog. Ser. 219, 1-10. doi: 10.3354/meps 219001

Falkowski, P., Scholes, R. J., Boyle, E., Canadell, J., Canfield, D., Elser, J., et al. (2000). The global carbon cycle: a test of our knowledge of earth as a system. Science 290, 291-296. doi: 10.1126/science.290.5490.291

Field, C. B., Behrenfeld, M. J., Randerson, J. T., and Falkowski, P. (1998). Primary production of the biosphere: integrating terrestrial and oceanic components. Science 281, 237-240. doi: 10.1126/science.281.5374.237

Galgani, L., and Engel, A. (2013a). Gel particles accumulation in the sea-surface microlayer. PANGAEA. doi: 10.1594/PANGAEA.814052

Galgani, L., and Engel, A. (2013b). Accumulation of gel particles in the seasurface microlayer during an experimental study with the diatom Thalassiosira weissflogii. Int. J. Geosci. 4, 129-145. doi: 10.4236/ijg.2013.41013

Galgani, L., Piontek, J., and Engel, A. (2016a). Biopolymers form a gelatinous microlayer at the air-sea interface when Arctic sea ice melts. Sci. Rep. 6:29465.

Galgani, L., Stolle, C., Endres, S., Schulz, K. G., and Engel, A. (2014). Effects of ocean acidification on the biogenic composition of the sea-surface microlayer: results from a mesocosm study. J. Geophys. Res. 119, 7911-7924. doi: $10.1002 / 2014$ JC010188

Galgani, L., Stolle, C., Endres, S., Schulz, K. G., and Engel, A. (2016b). Surface microlayer data during KOSMOS 2011 mesocosm experiment in the raunefjord. PANGAEA. doi: 10.1594/PANGAEA.859820

Gärdes, A., Ramaye, Y., Grossart, H. P., Passow, U., and Ullrich, M. S. (2012). Effects of Marinobacter adhaerens HP15 on polymer exudation by Thalassiosira weissflogii at different N:P ratios. Mar. Ecol. Prog. Ser. 461, 1-14. doi: 10.3354/meps09894

Glibert, P. M., and Bronk, D. A. (1994). Release of dissolved organic nitrogen by marine diazotrophic cyanobacteria, Trichodesmium spp. Appl. Environ. Microbiol. 60, 3996-4000.

Gobler, C. J., Hutchins, D. A., Fisher, N. S., Cosper, E. M., and SanudoWilhelmy, S. A. (1997). Release and bioavailability of C, N, P, Se, and Fe following viral lysis of a marine chrysophyte. Limnol. Oceanogr. 42, 1492-1504. doi: 10.4319/lo.1997.42.7.1492

Grossart, H. P., Czub, G., and Simon, M. (2006). Algae-bacteria interactions and their effects on aggregation and organic matter flux in the sea. Environ. Microbiol. 8, 1074-1084. doi: 10.1111/j.1462-2920.2006.00999.x

Hedges, J. I., Baldock, J. A., Gelinas, Y., Lee, C., Peterson, M. L., and Wakeham, S. G. (2002). The biochemical and elemental compositions of marine plankton: a NMR perspective. Mar. Chem. 78, 47-63. doi: 10.1016/S0304-4203(02) 00009-9

Hu, S. H., and Smith, W. O. (1998). The effects of irradiance on nitrate uptake and dissolved organic nitrogen release by phytoplankton in the Ross Sea. Cont. Shelf Res. 18, 971-990. doi: 10.1016/S0278-4343(98)00021-1

Huang, Q., Liu, L., Qin, B., Cai, X., Zhu, G., Zhang, Y., et al. (2016). Abundance, characteristics, and size spectra of transparent exopolymer particles and Coomassie stainable particles during spring in a large shallow lake, Taihu, China. J. Great Lakes Res. 42, 455-463. doi: 10.1016/j.jglr.2016. 01.007 
Hunter, K. A. (1997). "Chemistry of the sea-surface microlayer," in The Sea Surface and Global Change, eds P. Liss and R. A. Duce (Cambridge: Cambridge University Press), 287-320.

IPCC (2014). Climate Change 2014: Synthesis Report. Contribution of Working Groups, I., II and III to the Fifth Assessment Report of the Intergovernmental Panel on Climate Change (Geneva: IPCC).

Jackson, G. A. (1990). A model of the formation of marine algal flocs by physical coagulation processes. Deep Sea Res. 37, 1197-1211. doi: 10.1016/0198-0149(90)90038-W

Kiørboe, T., Tiselius, P., Mitchell-Innes, B., Hansen, J. L. S., Visser, A. W., and Mari, X. (1998). Intensive aggregate formation with low vertical flux during an upwelling-induced diatom bloom. Limnol. Oceanogr. 43, 104-116. doi: 10.4319/lo.1998.43.1.0104

Kujawinski, E. B. (2011). The impact of microbial metabolism on marine dissolved organic matter. Annu. Rev. Mar. Sci. 3, 567-599. doi: 10.1146/annurev-marine-120308-081003

Kuznetsova, M., Lee, C., and Aller, J. (2005). Characterization of the proteinaceous matter in marine aerosols. Mar. Chem. 96, 359-377. doi: 10.1016/j.marchem.2005.03.007

Leck, C., and Bigg, E. K. (2005). Source and evolution of the marine aerosol - a new perspective. Geophys. Res. Lett. 32:4. doi: 10.1029/2005GL023651

Leck, C., and Bigg, E. K. (2008). Comparison of sources and nature of the tropical aerosol with the summer high Arctic aerosol. Tellus B 60, 118-126. doi: 10.1111/j.1600-0889.2007.00315.x

Lemarchand, C., Jardillier, L., Carrias, J. F., Richardot, M., Debroas, D., SimeNgando, T., et al. (2006). Community composition and activity of prokaryotes associated to detrital particles in two contrasting lake ecosystems. FEMS Microbiol. Ecol. 57, 442-451. doi: 10.1111/j.1574-6941.2006.00131.x

Logan, B. E., Grossart, H. P., and Simon, M. (1994). Direct observation of phytoplankton, TEP and aggregates on polycarbonate filters using brightfield microscopy. J. Plankton Res. 16, 1811-1815. doi: 10.1093/plankt/16. 12.1811

Long, R. A., and Azam, F. (1996). Abundant protein-containing particles in the sea. Aquat. Microb. Ecol. 10, 213-221. doi: 10.3354/ame010213

Longhurst, A., Sathyendranath, S., Platt, T., and Caverhill, C. (1995). An estimate of global primary production in the ocean from satellite radiometer data. $J$. Plankton Res. 17, 1245-1271. doi: 10.1093/plankt/17.6.1245

Longnecker, K., and Kujawinski, E. B. (2017). Mining mass spectrometry data: using new computational tools to find novel organic compounds in complex environmental mixtures. Org. Geochem. 110, 92-99. doi: 10.1016/j.orggeochem.2017.05.008

Longnecker, K., Soule, M. C. K., and Kujawinski, E. B. (2015). Dissolved organic matter produced by Thalassiosira pseudonana. Mar. Chem. 168, 114-123. doi: 10.1016/j.marchem.2014.11.003

Luef, B., Aspetsberger, F., Hein, T., Huber, F., and Peduzzi, P. (2007). Impact of hydrology on free-living and particle-associated microorganisms in a river floodplain system (Danube, Austria). Freshw. Biol. 52, 1043-1057. doi: 10.1111/j.1365-2427.2007.01752.x

Mari, X. (1999). Carbon content and C: N ratio of transparent exopolymeric particles (TEP) produced by bubbling exudates of diatoms. Mar. Ecol. Prog. Ser. 183, 59-71. doi: 10.3354/meps183059

Mari, X. (2008). Does ocean acidification induce an upward flux of marine aggregates? Biogeosciences 5, 1023-1031. doi: 10.5194/bg-5-1023-2008

Mari, X., Beauvais, S., Lemee, R., and Pedrotti, M. L. (2001). Non-Redfield C: N ratio of transparent exopolymeric particles in the northwestern Mediterranean Sea. Limnol. Oceanogr. 46, 1831-1836. doi: 10.4319/lo.2001.46.7.1831

Mari, X., and Dam, H. G. (2004). Production, concentration, and isolation of transparent exopolymeric particles using paramagnetic functionalized microspheres. Limnol. Oceanogr. Methods 2, 13-24. doi: 10.4319/lom. 2004.2.13

Mari, X., Passow, U., Migon, C., Burd, A. B., and Legendre, L. (2017). Transparent exopolymer particles: effects on carbon cycling in the ocean. Prog. Oceanogr. 151, 13-37. doi: 10.1016/j.pocean.2016.11.002

Mari, X., and Robert, M. (2008). Metal induced variations of TEP sticking properties in the southwestern lagoon of New Caledonia. Mar. Chem. 110, 98-108. doi: 10.1016/j.marchem.2008.02.012

Mari, X., Torreton, J. P., Claire, B. T. T., Bouvier, T., Thuoc, C. V., Lefebvre, J. P., et al. (2012). Aggregation dynamics along a salinity gradient in the
Bach Dang estuary, North Vietnam. Estuar. Coast. Shelf Sci. 96, 151-158. doi: 10.1016/j.ecss.2011.10.028

Mojica, K. D., Huisman, J., Wilhelm, S. W., and Brussaard, C. P. (2016), Latitudinal variation in virus-induced mortality of phytoplankton across the North Atlantic Ocean. ISME J. 10, 500-513. doi: 10.1038/ismej.2015.130

Møller, E. F. (2007). Production of dissolved organic carbon by sloppy feeding in the copepods Acartia tonsa, Centropages typicus, and Temora longicornis. Limnol. Oceanogr. 52, 79-84. doi: 10.4319/lo.2007.52.1.0079

Møller, E. F., Thor, P., and Nielsen, T. G. (2003). Production of DOC by Calanus finmarchicus, C. glacialis and C. hyperboreus through sloppy feeding and leakage from fecal pellets. Mar. Ecol. Prog. Ser. 262, 185-191. doi: $10.3354 /$ meps 262185

Mopper, K., Zhou, J. A., Ramana, K. S., Passow, U., Dam, H. G., and Drapeau, D. T. (1995). The role of surface-active carbohydrates in the flocculation of a diatom bloom in a mesocosm. Deep Sea Res. II 42, 47-73. doi: 10.1016/0967-0645(95)00004-A

Myklestad, S. M. (2000). "Dissolved organic carbon from phytoplankton," in The Handbook of Environmental Chemistry (D). Marine Chemistry, ed P. Wangersky (Berlin: Springer Verlag), 111-148.

O’Dowd, C. D., Facchini, M. C., Cavalli, F., Ceburnis, D., Mircea, M., Decesari, S., et al. (2004). Biogenically driven organic contribution to marine aerosol. Nature 431, 676-680. doi: 10.1038/nature02959

Orellana, M. V., Lessard, E. J., Dycus, E., Chin, W. C., Foy, M. S., and Verdugo, P. (2003). Tracing the source and fate of biopolymers in seawater: application of an immunological technique. Mar. Chem. 83, 89-99. doi: 10.1016/S0304-4203(03)00098-7

Orellana, M. V., Matrai, P. A., Leck, C., Rauschenberg, C. D., Lee, A. M., and Coz, E. (2011). Marine microgels as a source of cloud condensation nuclei in the high Arctic. P. Natl. Acad. Sci. U.S.A. 108, 13612-13617. doi: $10.1073 /$ pnas.1102457108

Orellana, M. V., Petersen, T. W., Diercks, A. H., Donohoe, S., Verdugo, P., and van den Engh, G. (2007). Marine microgels: optical and proteornic fingerprints. Mar. Chem. 105, 229-239. doi: 10.1016/j.marchem.2007.02.002

Passow, U. (2000). Formation of transparent exopolymer particles, TEP, from dissolved precursor material. Mar. Ecol. Prog. Ser. 192, 1-11. doi: 10.3354/meps192001

Passow, U. (2002a). Transparent exopolymer particles (TEP) in aquatic environments. Progr. Oceanogr. 55, 287-333. doi: 10.1016/S0079-6611(02)00138-6

Passow, U. (2002b). Production of transparent exopolymer particles (TEP) by phyto- and bacterioplankton. Mar. Ecol. Prog. Ser. 236, 1-12. doi: $10.3354 /$ meps236001

Passow, U., and Alldredge, A. L. (1995). A dye-binding assay for the spectrophotometric measurement of transparent exopolymer particles (TEP). Limnol. Oceanogr. 40, 1326-1335. doi: 10.4319/lo.1995.40. 7.1326

Paul, C., Barofsky, A., Vidoudez, C., and Pohnert, G. (2009). Diatom exudates influence metabolism and cell growth of co-cultured diatom species. Mar. Ecol. Prog. Ser. 389, 61-70. doi: 10.3354/meps08162

Prieto, L., Ruiz, J., Echevarria, F., Garcia, C. M., Bartual, A., Galvez, J. A., et al. (2002). Scales and processes in the aggregation of diatom blooms: high time resolution and wide size range records in a mesocosm study. Deep Sea Res. I 49, 1233-1253. doi: 10.1016/S0967-0637(02)00024-9

Quinn, P. K., and Bates, T. S. (2011). The case against climate regulation via oceanic phytoplankton sulphur emissions. Nature 480, 51-56. doi: 10.1038 /nature10580

Radić, T., Ivančić, I., Fuks, D., and Radić, J. (2006). Marine bacterioplankton production of polysaccharidic and proteinaceous particles under different nutrient regimes. FEMS Microbiol. Ecol. 58, 333-342. doi: 10.1111/j.1574-6941.2006.00176.x

Redfield, A. C. (1958). The biological control of chemical factors in the environment. Am. Sci. 46, 205-221.

Romera-Castillo, C., Sarmento, H., Alvarez-Salgado, X. A., Gasol, J. M., and Marrase, C. (2010). Production of chromophoric dissolved organic matter by marine phytoplankton. Limnol. Oceanogr. 55, 446-454. doi: 10.4319/lo.2010.55.1.0446

Russell, L. M., Hawkins, L. N., Frossard, A. A., Quinn, P. K., and Bates, T. S. (2010). Carbohydrate-like composition of submicron atmospheric particles and 
their production from ocean bubble bursting. Proc. Natl. Acad. Sci. U.S.A. 107, 6652-6657. doi: 10.1073/pnas.0908905107

Stedmon, C. A., and Markager, S. (2005). Tracing the production and degradation of autochthonous fractions of dissolved organic matter by fluorescence analysis. Limnol. Oceanogr. 50, 1415-1426. doi: 10.4319/lo.2005.50.5.1415

Suratman, S., Weston, K., Jickells, T., Chance, R., and Bell, T. (2008). Dissolved organic matter release by an axenic culture of Emiliania huxleyi. J. Mar. Biol. Assoc. UK 88, 1343-1346. doi: 10.1017/S0025315408002026

Suter, E. A., Scranton, M. I., Chow, S., Stinton, D., Faull, L. M., and Taylor, G. T. (2017). Niskin bottle sample collection aliases microbial community composition and biogeochemical interpretation. Limnol. Oceanogr. 62, 606-617. doi: 10.1002/lno.10447

Taylor, J. D., and Cunliffe, M. (2014). High-throughput sequencing reveals neustonic and planktonic microbial eukaryote diversity in coastal waters. $J$. Phycol. 50, 960-965. doi: 10.1111/jpy.12228

Thornton, D. C. O. (2002). Diatom aggregation in the sea: mechanisms and ecological implications. Eur. J. Phycol. 37, 149-161. doi: $10.1017 /$ S0967026202003657

Thornton, D. C. O. (2014). Dissolved organic matter (DOM) release by phytoplankton in the contemporary and future ocean. Eur. J. Phycol. 49, 20-46. doi: 10.1080/09670262.2013.875596

Thornton, D. C. O., Brooks, S. D., and Chen, J. (2016). Protein and carbohydrate exopolymer particles in the sea surface microlayer (SML). Front. Mar. Sci. 3:135. doi: $10.3389 /$ fmars.2016.00135

Thornton, D. C. O., and Chen, J. (2017). Exopolymer production as a function of cell permeability and death in a diatom (Thalassiosira weissflogii) and a cyanobacterium (Synechococcus elongatus). J. Phycol. 53, 245-260. doi: 10.1111/jpy.12470

Tolić, N., Liu, Y., Liyu, A., Shen, Y. F., Tfaily, M. M., Kujawinski, E. B., et al. (2017). Formularity: software for automated formula assignment of natural and other organic matter from ultrahigh-resolution mass spectra. Anal. Chem. 89, 12659-12665. doi: 10.1021/acs.analchem.7b03318

Westberry, T., Behrenfeld, M. J., Siegel, D. A., and Boss, E. (2008). Carbon-based primary productivity modeling with vertically resolved photoacclimation. Global Biogeochem. Cycles 22:Gb2024. doi: 10.1029/2007GB0 03078

Wilson, T. W., Ladino, L. A., Alpert, P. A., Breckels, M. N., Brooks, I. M., Browse, J., et al. (2015). A marine biogenic source of atmospheric ice-nucleating particles. Nature 525, 234-238. doi: 10.1038/nature14986

Wurl, O., and Holmes, M. (2008). The gelatinous nature of the seasurface microlayer. Mar. Chem. 110, 89-97. doi: 10.1016/j.marchem.2008. 02.009

Wurl, O., Wurl, E., Miller, L., Johnson, K., and Vagle, S. (2011). Formation and global distribution of sea-surface microlayers. Biogeosciences 8, 121-135. doi: 10.5194/bg-8-121-2011

Zhang, Z. B., Liu, L. S., Liu, C. Y., and Cai, W. J. (2003). Studies on the sea surface microlayer - II. The layer of sudden change of physical and chemical properties. J. Colloid Interface Sci. 264, 148-159. doi: 10.1016/S0021-9797(03) 00390-4

Conflict of Interest Statement: The author declares that the research was conducted in the absence of any commercial or financial relationships that could be construed as a potential conflict of interest.

Copyright (๑) 2018 Thornton. This is an open-access article distributed under the terms of the Creative Commons Attribution License (CC BY). The use, distribution or reproduction in other forums is permitted, provided the original author(s) and the copyright owner are credited and that the original publication in this journal is cited, in accordance with accepted academic practice. No use, distribution or reproduction is permitted which does not comply with these terms. 